\title{
Thermodynamic modeling for an incrementally fractionated granite magma system: Implications for the origin of igneous charnockite
}

\author{
Kai Zhao ${ }^{\text {a }}$, Xisheng Xu ${ }^{\text {a,* }}$, Saskia Erdmann ${ }^{\text {b,a }}$ \\ ${ }^{\mathrm{a}}$ State Key Laboratory for Mineral Deposits Research, School of Earth Sciences and Engineering, Nanjing University, Nanjing, 210023, China ${ }^{\mathrm{b}}$ \\ Université d'Orléans - CNRS/INSU - ISTO - BRGM, UMR 7327, Orléans, France
}

article info

Article history:

Received 15 November 2017 Received in

revised form 24 July 2018 Accepted 25

July 2018

Available online 3 August 2018

Editor: T.A. Mather

\section{Keywords:}

peraluminous charnockite

incremental fractionation

cumulate granite

thermodynamic modeling

open-system magma fractionation

\begin{abstract}
a b s ract
Understanding fractionation of silicic magma is crucial to advance our knowledge of differentiation of continental crust, enrichment of elements of economic interest, and plutonic-volcanic connection. Microstructural records afford critical appraisals for silicic magma fractionation, yet are rarely reported in granite plutons. Here we combine detailed microstructural observations and thermodynamic modeling to quantify the components and the conditions of silicic magma fractionation using the peraluminous Jiuzhou pluton (South China) as an example. The pluton shows compositional gradients from primitive orthopyroxene-bearing granite (charnockite) at stratigraphically low levels to relatively evolved orthopy-roxene-free granite at stratigraphically high levels. Deviation of whole-rock compositions from metasediment-sourced experimental melts, and stepzoned plagioclase and alkali feldspar crystals in the exposed rocks suggest open-system fractionation by melt extraction, partial dissolution, and subsequent crystallization from trapped minimum melt. Crystal cluster and chain fabrics and viscous deformation are more abundant in the charnockites than in the overlying orthopyroxene-free granites, suggesting that gravitational, compaction-driven fractionation increased towards the bottom of the pluton. Field observations, thermodynamic modeling and petrographic studies further demonstrate that gravitational compaction reduces the trapped melt fraction of a crystal mush with thickness of $\geq 100 \mathrm{~m}$ from $\sim 30 \mathrm{wt} \%$ at the upper level to $\sim 10 \mathrm{wt} \%$ at the lower level of the pluton. Significant melt extraction restricted back-reaction with high-temperature phases during progressive crystallization, which preserved orthopyroxene during the solidification of granitic magma. The compositional, mineralogical and textural zoning of the Jiuzhou pluton suggests that incremental fractionation of granite systems may be an important process that produces compositionally zoned cumulate. Incremental fractionation may occur in many zoned granite plutons worldwide, causing their whole-rock composition to deviate from their primary melt composition. Detailed microstructural examination for these granite plutons may provide insights into the mechanism(s) for melt extraction and crystal accumulation of silicic magma, providing key insights towards quantifying fractionation of magma systems.
\end{abstract}

\section{Introduction}

Magma fractionation plays an important role in the forma-tion and differentiation of the continental crust (e.g. Keller et al., 2015), and in the enrichment of elements of economic interest (e.g. Mustard et al., 2006). Many studies on low-viscosity, mafic layered magma series have suggested that cumulate formation by gravitational settling is a key process of magma fractionation (e.g. Wager et al., 1960). Other studies have advocated that cumulates form by in situ crystallization in solidification fronts and subse-

\footnotetext{
* Corresponding author.

E-mail addresses: kaivino920@hotmail.com (K. Zhao), xsxu@nju.edu.cn (X. Xu), saskia.erdmann@cnrs-orleans.fr (S. Erdmann).
}

quent removal of evolved melt (e.g. Latypov and Egorova, 2012; Holness et al., 2017). Silicic magmas have been considered to be largely stagnant during much of their lifetime in crustal reser-voirs, given their high viscosities (e.g. Huber et al., 2009; Glazner, 2014), but vigorous magma-flow-driven crystalliquid segregation of crystal-rich magma is at least locally recorded (Paterson et al., 1998; Zak et al., 2007). The formation of crystal-poor rhyo-lites or other evolved melts (e.g. aplites) requires efficient seg-regation of melts from crystal mush through hindered settling, compaction and/or filter pressing (Bachmann and Bergantz, 2004; Gelman et al., 2014). Direct microstructural evidence for melt ex-traction and crystal accumulation, however, is rarely examined in intrusive magma bodies (Fiedrich et al., 2017), and mechanisms 


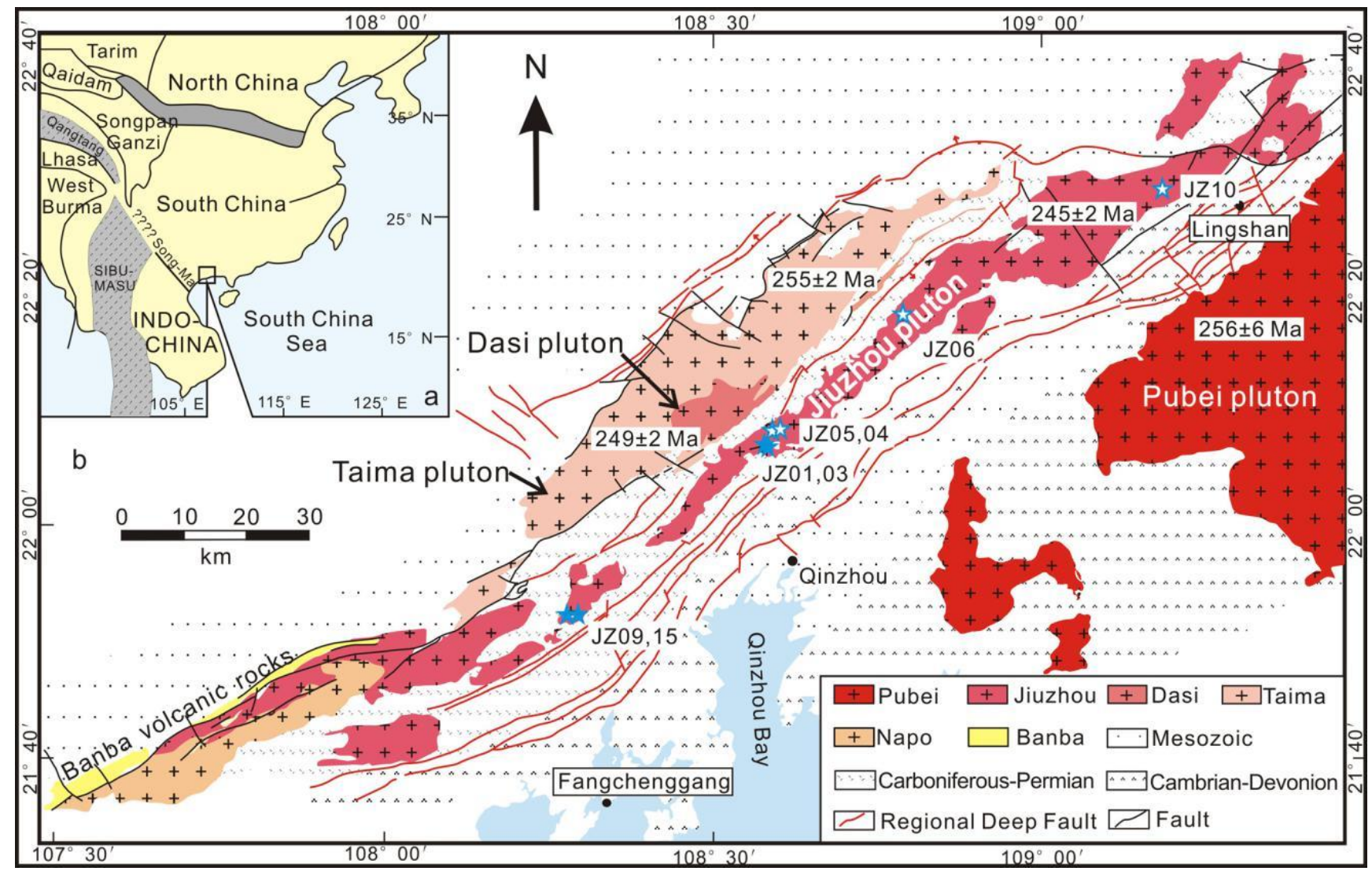

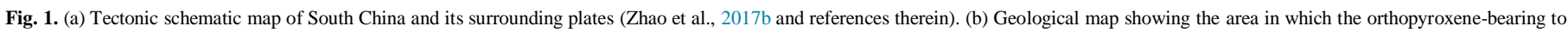
orthopyroxene-free Jiuzhou pluton is exposed. Filled and open stars within the Jiuzhou pluton mark our sample locations for charnockite and orthopyroxene-free granite, respectively.

of melt-crystal segregation thus commonly remain hypothetical (Holness, 2018).

Thermodynamic modeling (e.g. the using of the rhyolite-MELTS, Magma Chamber Simulator, or Perple_X program packages) is a powerful tool for constraining phase relationships, intensive crys-tallization parameters, and the compositional evolution of liquids and solids (e.g. Connolly, 2005; Gualda et al., 2012; Spera and Bohrson, 2001; Zhao et al., 2017a). The basic requirement for the application of most thermodynamic models is that the systems considered have approached total equilibrium (i.e. equilibrium for all chemical components and phases in the system) or at least lo-cal equilibrium (i.e. equilibrium for crystal rims and host liquids) in a compositionally closed system. Mass and energy exchange as a result of open-system processes, e.g. magma recharge, assimilation, and fractional crystallization (leading to melt and/or volatile loss), may cause partial disequilibrium on the mineral scale, e.g. crystal zoning (Humphreys, 2009), and deviation of whole-rock compositions from those of primary melts (e.g. Montel and Vielzeuf, 1997). The open-system evolution of magma systems through the addi-tion of material, e.g. magma recharge or country-rock assimilation (Spera and Bohrson, 2001), has been numerically constrained for many systems. Modeling the compositional and the mineralogi-cal effects resulting from the loss of liquids from evolving magma systems is still rare (with few exceptions, such as the studies of Gelman et al., 2014; Lee and Morton, 2015), yet crucial for quantifying parental magma composition and intensive system variables.

This study investigates such open-system evolution, using the peraluminous Jiuzhou pluton, South China, as an example. The pluton comprises orthopyroxene-bearing granite (charnockite) and orthopyroxenefree granite with assemblages that permit the char-acterization of crystallization pressure, temperature, and melt $\mathrm{H}_{2} \mathrm{O}$ content. Previous work has shown that the system likely experi-enced partial melt extraction, which was crucial for the preser-vation of orthopyroxene in solidification of granite magma (Zhao et al., 2017a). To further assess possible melt extraction, and to quantify the magmatic system evolution, we have (1) carried out geochemical modeling to evaluate the potential magmatic pro-cesses including magma mixing, restite entrainment and fractional crystallization, and (2) characterized the pluton- and mineral-scale processes of magmatic evolution using whole-rock compositions, mineral textures and compositions, crystal size distribution, mi-crostructure, and thermodynamic modeling utilizing the Perple_X program package of Connolly (2005). Our approach can be applied to constrain the role of melt extraction and cumulate formation in $\mathrm{H}_{2} \mathrm{O}$-poor to moderately $\mathrm{H}_{2} \mathrm{O}$-rich granitic magma systems, which may contribute new insights into the processes and the conditions of granite fractionation that lead to compositional zoning and de-viation of whole-rock composition from primary melt composition.

\section{Geological background}

The Qinzhou Bay Granitic Complex (QBGC), South China, com-prises several strongly peraluminous (ASI > 1.1) granitic intru-sions including the orthopyroxene-bearing to orthopyroxene-free Jiuzhou pluton (Fig. 1). The granitic rocks are classified as S-type granites derived from partial melting of a crustal source with minor or no input of mantle-derived magma (Qi et al., 2007; Zhao et al., 2012; Jiao et al., 2015). Restitic granulite enclaves hosted by the Jiuzhou pluton are inferred to record source partial melting at $\sim 0.7-0.8$ $\mathrm{GPa}$ and $\sim 900-1000{ }^{\circ} \mathrm{C}$ and granite emplace-ment at $\sim 0.2-0.3 \mathrm{GPa}$ (Zhao et al., 2017b). 

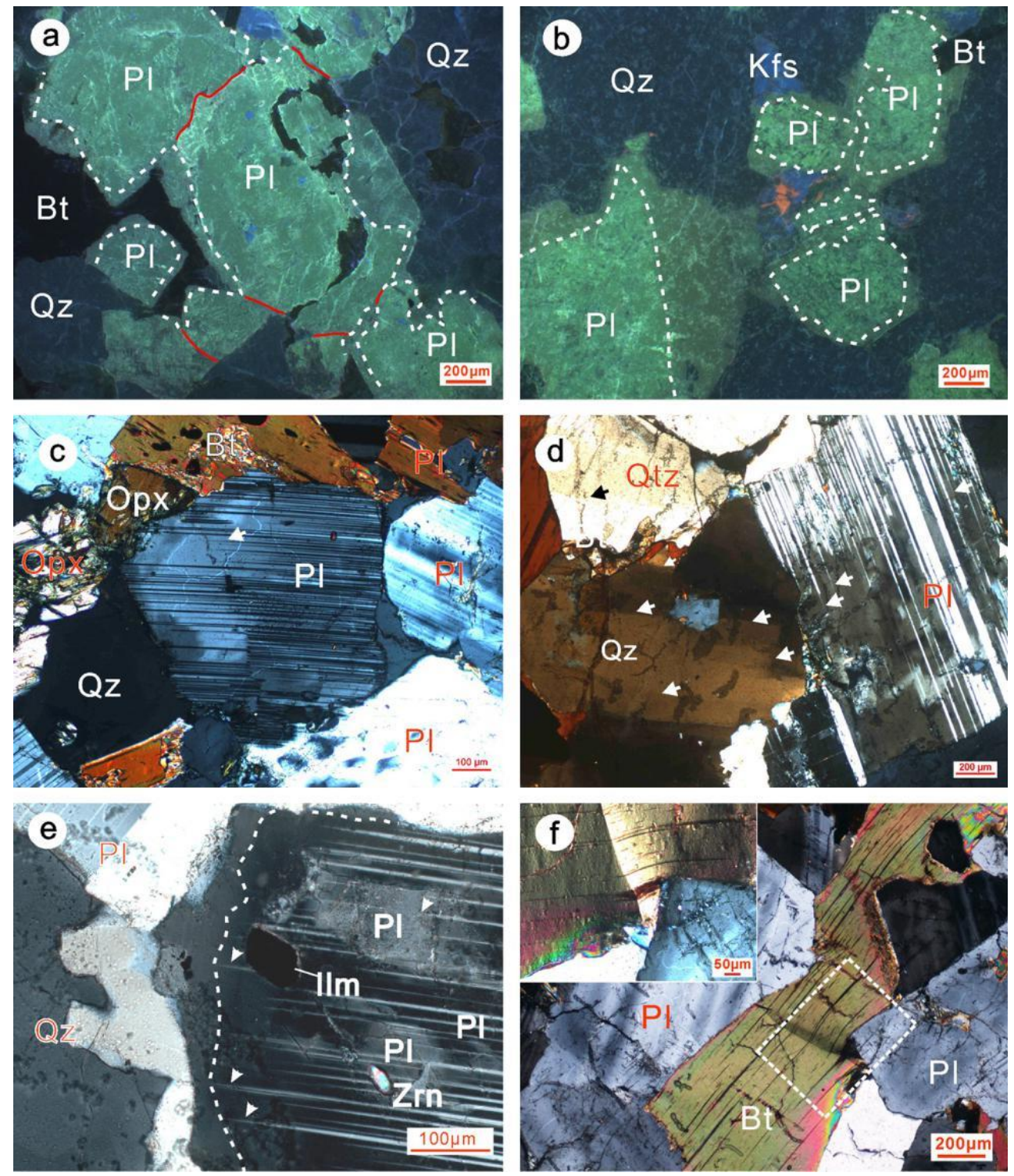

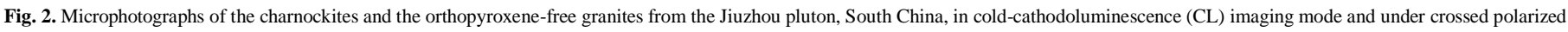

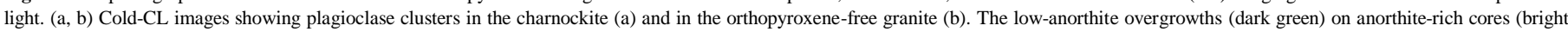

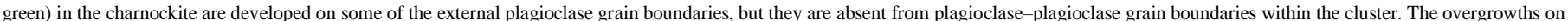

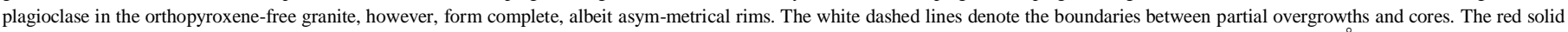

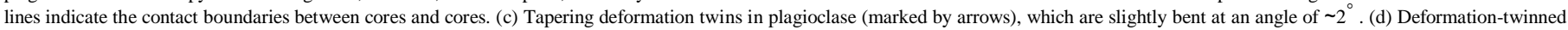

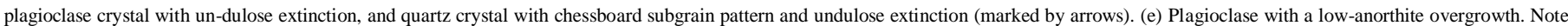

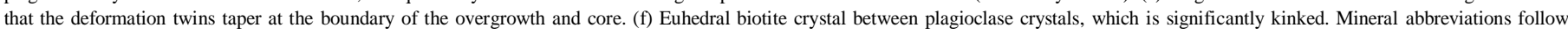
Whitney and Evans (2010). (For interpretation of the colors in the figure(s), the reader is referred to the web version of this article.)

\section{Mineralogy and petrology of the Jiuzhou pluton}

\subsection{Field relations, microtexture and microstructure}

The Jiuzhou pluton is exposed over $\sim 200$ by $\sim 10 \mathrm{~km}$ extend-ing in NESW direction (Fig. 1). The charnockites crop out in the southwest part of the intrusion, while the northeast part of the in-trusion exposes orthopyroxenefree granites. The charnockite sam-ples moreover crop out at lower altitude than the orthopyroxene-free granite samples, i.e. at $<150 \mathrm{~m}$ versus $>150 \mathrm{~m}$ above sea level (Table S1 in supplementary file 1).

The charnockites are massive, and layering or a preferred fab-ric are not evident on the outcrop scale, while the samples show a weak preferred fabric on the hand specimen- and the micro-scale. Plagioclase crystals are euhedral or subhedral with a low apparent aspect ratio of $\sim 1.0: 1.2: 1.8\left(\mathrm{R}^{2}=0.9\right)$. They locally form monomin-eralic clusters (Fig. 2a) and chains (Fig. 3a). Some of the crystals show undulose extinction, mechanical twins (Fig. 2c-e), and/or subgrains (Fig. 2d). Rarely, the crystals are also slightly bent (by $<2^{\circ}$, Fig. 2 c). The plagioclase crystal size distribution (CSD) curves show upward concave deflections for large grain sizes (>3.8 mm), except for sample JZ09 with an approximately linear CSD, while they have decreasing grain numbers at crystal sizes of $<1 \mathrm{~mm}$ (Fig. 4). Quartz crystals are subhedral to anhedral and slightly elongated (Fig. 3a). They commonly show undulose extinction or chessboard subgrain patterns (Fig. 2d). Alkali feldspar crystals have subhedral to anhedral shape with tendrils locally extending into the matrix (Fig. 3a). Some of the crystals show a preferred ori-entation with their long axis sub-parallel to the main plagioclase chains (Fig. 3a). Few of the crystals also show subgrains and/or 
(a) JZ01-1

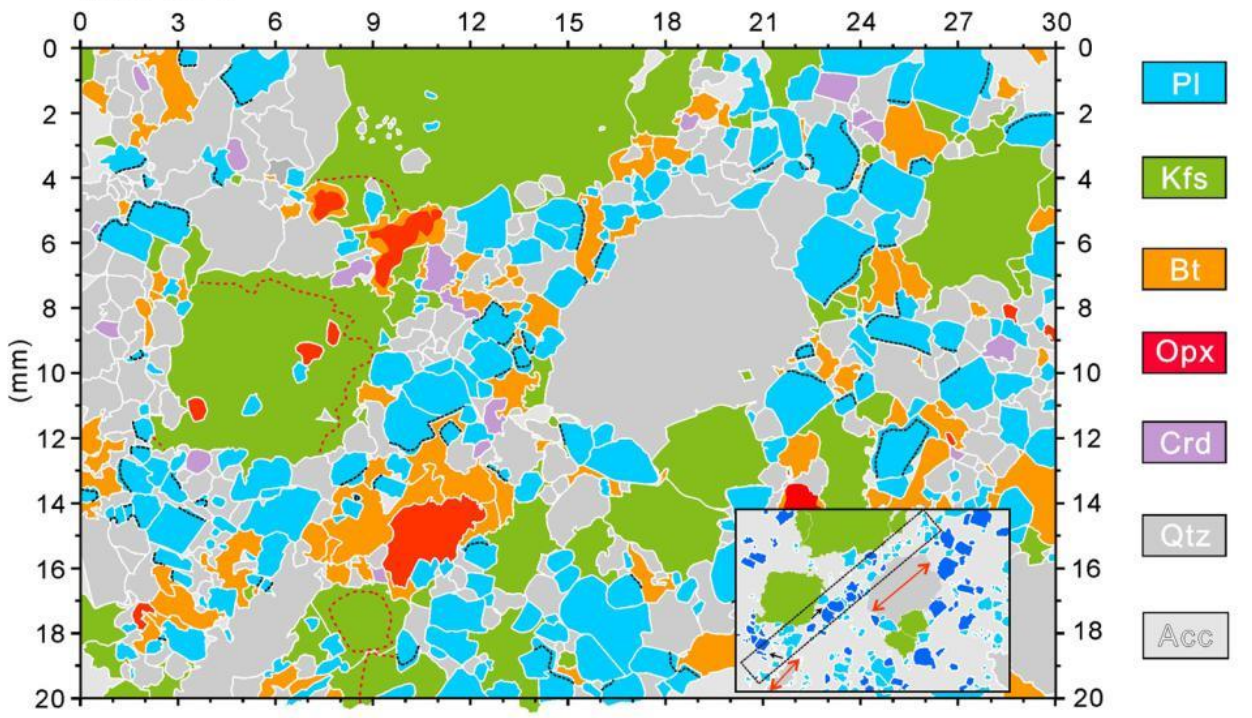

(b) JZ10

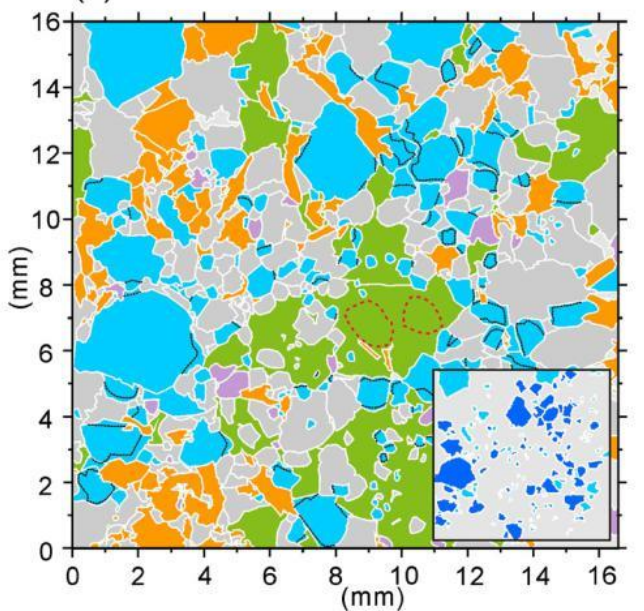

(c) JZ06

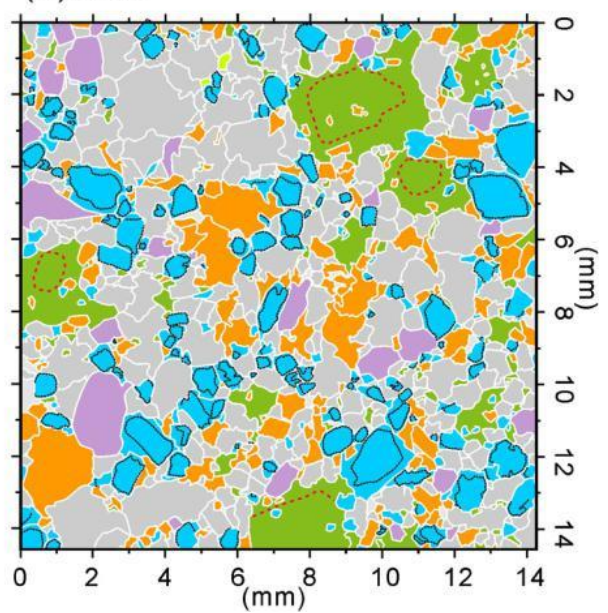

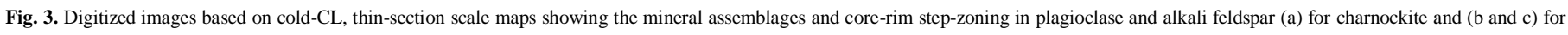

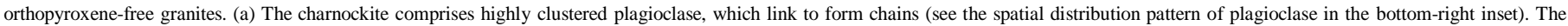

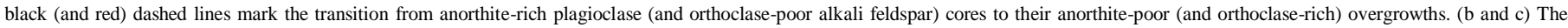

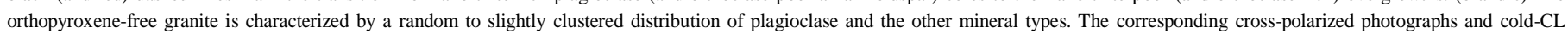
images are provided in supplementary file 1 (Figs. S1 and S2). Acc in the legend represent accessories or epoxy.

undulose extinction. Biotite crystals are present as either single crystals with euhedral to subhedral shape or as anhedral crys-tals surrounding orthopyroxene. Some of the euhedral crystals are significantly bent (by up to $\sim 20^{\circ}$ ) or kinked (Fig. $2 \mathrm{f}$ and Fig. S3 in supplementary file 1). Cordierite crystals are locally present as subhedral-euhedral crystals or as inclusions in orthopyroxene, plagioclase, and alkali feldspar. Deformation features in cordierite have not been observed, but they may have been obliterated by its significant sericitization. Orthopyroxene crystals are present as eu-hedral crystals and as subhedral to anhedral crystals with irregular grain boundary outlines against partial or complete rims of biotite (Fig. 2c). Orthopyroxene shows no deformation features.

The orthopyroxene-free granites are massive, showing no layer-ing or a preferred fabric on outcrop-, hand specimen-, or micro-scale. Plagioclase crystals are euhedral to subhedral with a low apparent aspect ratio of $\sim 1.0: 1.3: 2.0 \quad\left(\mathrm{R}^{2}=0.8\right)$. They show a ran-dom to slightly clustered distribution (Fig. 3b, c). Contrary to the charnockites, plagioclase in the orthopyroxene-free granites shows no mechanical twinning or subgrains. The plagioclase CSDs are ap-proximately linear at crystal sizes of $>1 \mathrm{~mm}$, while they show de- creasing grain numbers at crystal sizes of $<1 \mathrm{~mm}$ (Fig. 4). Quartz crystals are subhedral to anhedral. They show no significant elon-gation or chessboard subgrain patterns, while undulose extinction is common. Alkali feldspar crystals are subhedral to poikilitic. De-formation features have not been observed. Biotite crystals are euhedral to subhedral. Deformation of biotite is rare, but weakly bent biotite with undulose extinction has been observed. Cordierite crystals are subhedral to euhedral, which are partly altered to finegrained sericite and chlorite. Garnet crystals (supplementary table 2) are occasionally present, which have subhedral to anhedral shape and biotite rims. Both cordierite and garnet show no evi-dence for deformation.

\subsection{Plagioclase and alkali feldspar compositions and zoning}

Plagioclase and alkali feldspar core-rim compositions were ac-quired using a JEOL JXA-8800 electron microprobe at Nanjing Uni-versity, China. Details of the method are described in supplemen-tary file 1. 


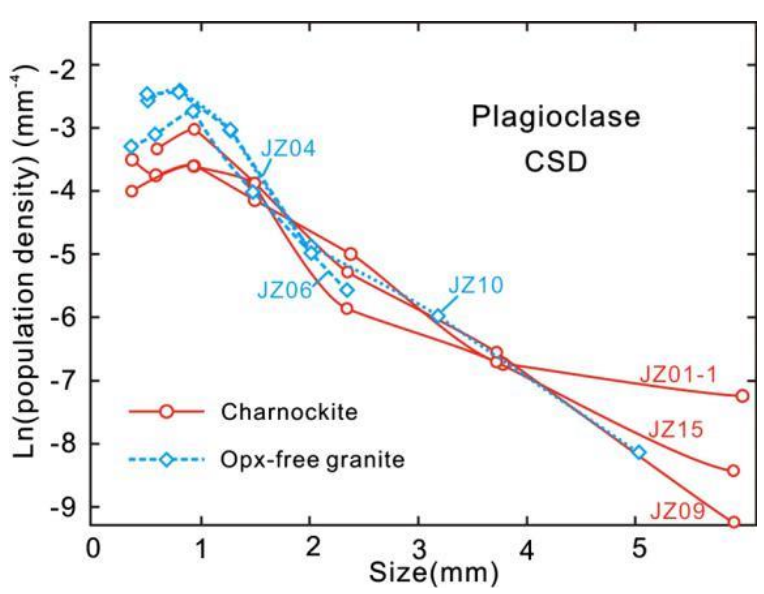

Fig. 4. Crystal size distribution (CSD) curves for plagioclase from the charnockite and the orthopyroxene-free granite of the Jiuzhou pluton. The curves are labeled with their sample numbers.

Plagioclase in the charnockite (sample JZ01-1) forms anorthite-rich crystals with weak oscillatory and gradual normal zoning, of which some show marginal step-zoning to anorthite-poor overgrowths. The anorthite-rich crystals, including the cores of the step-zoned crystals, have $\sim$ An60-45 composition (on average $\sim$ An50) (Fig. 5). The anorthite-poor overgrowths have $\sim$ An $42-30$ and on average $\sim$ An36 composition (Fig. 5). The plagioclase crys-tals thus show a significantly bimodal composition with a compo-sitional gap at $\sim$ An45-42 (Fig. 5c). The anorthite-poor overgrowths are asymmetrical and typically $<100 \mu \mathrm{m}$ wide (Fig. 5a). They are present on one or more crystal surfaces, forming partial rims. They are absent from plagioclaseplagioclase grain boundaries in pla-gioclase clusters and chains (Fig. 2a), but occur against all other mineral types. The plagioclase-plagioclase grain boundaries are characterized by long, mostly straight and at times slightly curved or serrated 2D outlines (Fig. 2a). The anorthite-rich cores occasionally show deformation twins, while deformation twins have not been observed in the overgrowths (Fig. 2e). Crystals with and without the anorthite-poor overgrowths have closely comparable shape and size. The plagioclase crystals with the anorthite-poor overgrowths are locally concentrated in the thin sections, where $\sim 30 \%$ of the crystals show stepzoning (Fig. 3a). Overall, the over-growths make up $\sim 2$ vol\% of the charnockite samples. Alkali feldspar also shows core-rim step zoning, where cores and over-growths have $\sim$ Or80 and $\sim$ Or85 composition, respectively. The overgrowths are partially developed. They make up a larger pro-portion of the samples ( $\sim$ vol\%) than the plagioclase overgrowths. and they are locally concentrated around the large phenocrysts (Fig. 3a). The overgrowths are devoid of undulose extinction or subgrains. zoning patterns as plagioclase in the charnockite (Fig. 5d, e). The anorthitepoor overgrowths are, however, more common and wider than those on plagioclase in the charnockite. They are developed on $\sim 50-90 \%$ of the crystals, typically forming their outer $\sim 100-300 \mu \mathrm{m}$ wide rims, amounting to $\sim 8-10$ vol\% of the samples. They are predominantly developed as complete rims in $2 \mathrm{D}$, they also occur on plagioclase-plagioclase grain bound-aries (Fig. $2 b$ ), and they occur throughout the samples (inset of Fig. 3b, c). The plagioclase crystal cores have $\sim$ An57-42 (on aver-age $\sim$ An47) composition, and they thus have lower anorthite con-tent than the plagioclase cores in the charnockite. The step-zoned, anorthite-poor overgrowths have $\sim$ An42-30 and on average $\sim$ An35. Cores and overgrowths of the plagioclase crystals do not show a compositional gap as they do in the charnockite, but $\sim$ An39-42 compositions are rare (Fig. 5f). Few of the alkali feldspar crystals also show core-rim step-zoning from $\sim$ Or85 cores to $\sim$ Or90 over-growths. The cores are completely mantled by the overgrowths, while the majority of the crystals have a composition equivalent to that of the overgrowths. Overgrowths and unzoned, orthoclase-rich crystals make up $\sim 10-12$ vol\% of the orthopyroxene-free granite samples.

\section{Constraints on the geochemical variation of the Jiuzhou pluton}

The Jiuzhou rocks define a continuous compositional trend for all major elements from low-SiO2 (63-67 wt\%) charnockites to high-SiO2 (68-70 wt\%) orthopyroxene-free granites (Fig. 6a-f). The compositions of the charnockites are significantly outside the compositional fields of experimentally produced, metapelite- and metagraywacke-derived partial melts (Fig. 6a-f). The orthopyrox-ene-free granites also differ from, but approach or partly over-lap with the composition of experimental melts (Fig. $6 \mathrm{a}-\mathrm{f}$ ). This suggests that most (or all) of the rocks exposed in the Jiuzhou pluton represent magmas that deviate from primary melt composi-tions. In the following sections, mass balance calculations are used to constrain the plutonscale processes that account for the Ji-uzhou whole-rock compositional variation. The phase compositions required in the calculation were determined by thermodynamic modeling using the Perple_X program (Connolly, 2005; version 6.7.4). Details of the method and modeling results are described in the supplementary file 1 .

\subsection{Possible restite entrainment}

Restite enclaves consisting of mainly garnet, cordierite, spinel, biotite, alkali feldspar, and minor orthopyroxene and plagioclase are locally present in the Jiuzhou pluton (Zhao et al., 2017b). The minerals in the enclaves form inclusion-rich porphyroblasts or subhedral-anhedral matrix crystals. Garnet crystals, which only locally occur in the orthopyroxene-free granite, have subhedral to anhedral shape and biotite rims, and they may thus repre-sent restite. The entrainment and bulk assimilation of the garnet-and cordieriterich source-derived restite would have significantly increased whole-rock

$\mathrm{Al}_{2} \mathrm{O}_{3}$ and $\mathrm{FeO}$ and decreased whole-rock $\mathrm{K}_{2} \mathrm{O}$ and $\mathrm{SiO}_{2}$ contents (Fig. $6 \mathrm{a}-$ f). The addition of 20-30 wt $\%$ restite to a magma with composition equivalent to the evolved orthopyroxene-free granites could have produced magmas with $\mathrm{SiO}_{2}-\mathrm{Al}_{2} \mathrm{O} 3-\mathrm{MgO}-\mathrm{FeO}-\mathrm{K}_{2} \mathrm{O}-\mathrm{Na} 2 \mathrm{O}$ compositions equivalent to the charnockites (Fig. $6 \mathrm{a}-\mathrm{b}, \mathrm{d}-\mathrm{f}$ ), but cannot account for the signifi-cantly higher $\mathrm{CaO}$ contents of the charnockites compared with the orthopyroxenefree granites (Fig. 6c).

\subsection{Possible fractionation in solidification fronts}

Fractionation of silicic magmas is thought to be inefficient at low crystallinities (i.e. at crystallinities of $<\sim 40 \mathrm{vol} \%$ ), but may become efficient when crystals form a framework and magma con-vection ceases (e.g., at crystallinities of > 40-50 vol\%; Bachmann and Bergantz, 2004). The continuous compositional trends and ver-tical zoning from relative primitive charnockite to more evolved, orthopyroxene-free granite may suggest incremental fractiona-tion, which means that magma may have crystallized in a so-lidification front, which incrementally advanced from the first cooled magma chamber margin into its later cooled center (i.e. in situ fractional crystallization, see box-model and Table S1 in supplementary file 1; Langmuir, 1989; Nishimura and Yanagi, 2000; Hertogen and Mareels, 2016). Some early solidification fronts may still contain melt when most of the original magma chamber was solid-rich given that significant near-solidus crys-tallization (cotectic, eutectic, or minimum crystallization) will 

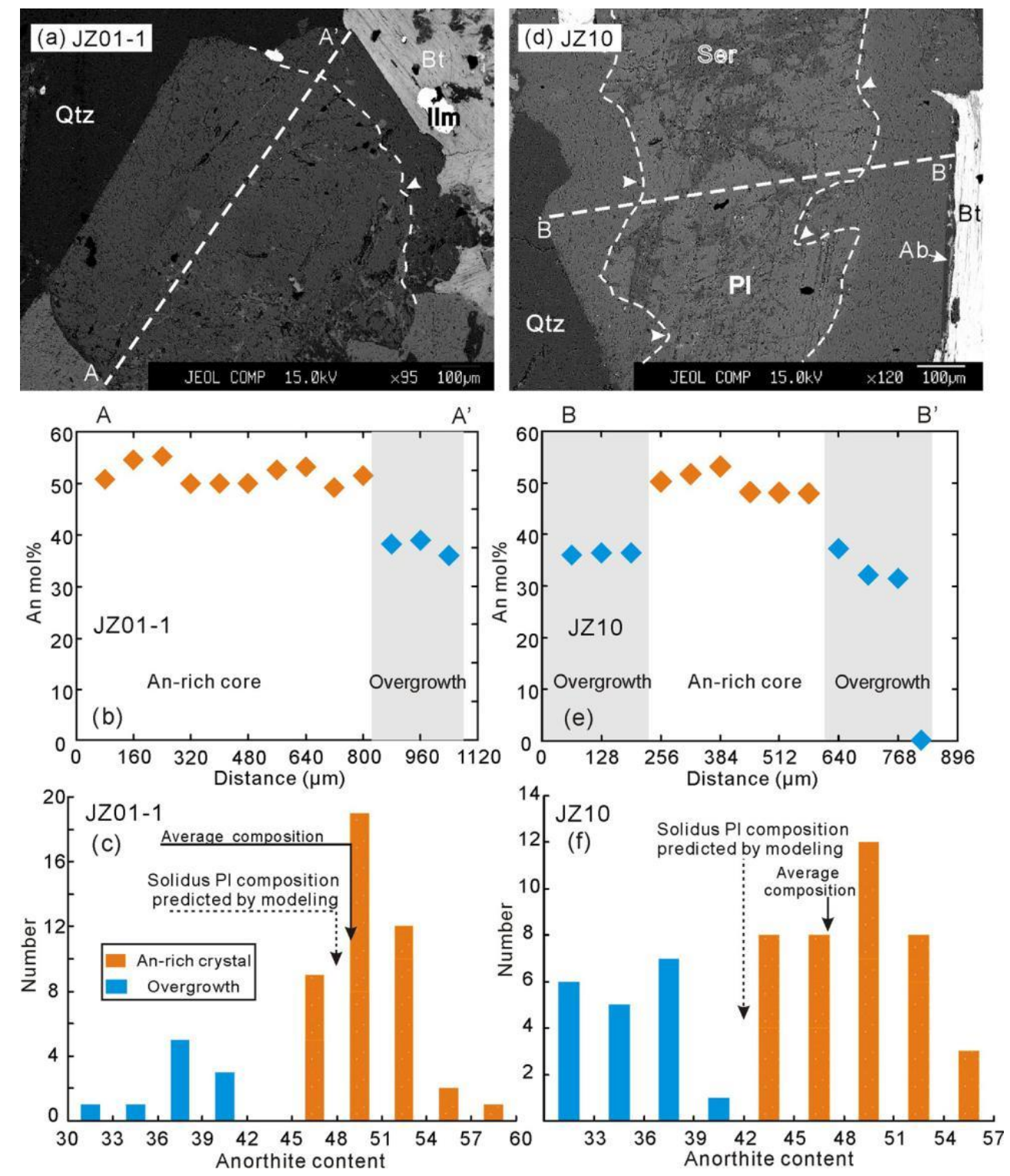

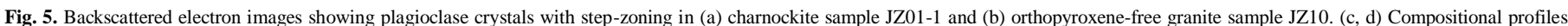

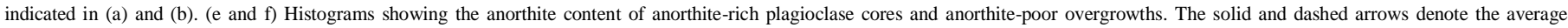

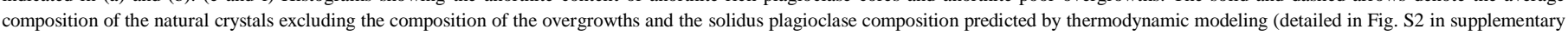
file 1).

buffer temperature across most of the system (cf. Huber et al., 2009).

To model such incremental fractionation, mass balance equa-tions were solved step-wise fashion. Free parameters used in the modeling are the solidification zone mass fraction (0.1-0.2, cf. Hertogen and Mareels, 2016), the critical crystallinity for melt ex-traction (0.4-0.5, cf. Bachmann and Bergantz, 2004), and the poros-ity of the cumulate pile. The porosity values were determined using thermodynamic modeling and plagioclase compositions (see section 5.2). The other input parameters were determined by ther-modynamic modeling. We highlight that different input values for the three parameters do not, in any case, change the direction of the modeling trends and our general conclusions, but they affect the absolute composition of each modeled increment/solidification zone. The higher the critical crystallinity and porosity values, the more felsic is the composition of the modeled cumulate pile, while the choice of solidification zone mass fraction only determines the coarseness of the modeling (e.g. see also Hertogen and Mareels, 2016). Further details of the modeling are provided in supplemen- tary file 1 , while the results are given in supplementary file 3 and summarized in Fig. 5a-f. The modeling predicts that the cumu-late pile (cumulus solid plus unextracted melt) has $\sim 62 \mathrm{wt} \%$ to $71 \mathrm{wt} \% \mathrm{SiO}_{2}$. The evolved magma in the residual chamber compris-ing $\sim 10 \%$ of the mass of the initial magma chamber is modeled to have reached $\sim 72 \mathrm{wt} \% \mathrm{SiO} 2$. The most felsic sample of the plu-ton (Fig. 6; Jiao et al., 2015) with $\sim 72 \mathrm{wt} \% \mathrm{SiO}_{2}$ may represent or at least approach the finial liquid-rich differentiates, which have a lower proportion $(<\sim 10 \mathrm{vol} \%)$ than the solid-rich cumulates. The modeled compositional variation thus matches the range of the Ji-uzhou whole-rock $\mathrm{SiO}_{2}$ contents, but also the corresponding $\mathrm{FeO}, \mathrm{MgO}, \mathrm{CaO}$, and $\mathrm{K}_{2} \mathrm{O}$ contents (Fig. $6 \mathrm{~b}, \mathrm{c}$ and d). The modeled $\mathrm{Al}_{2} \mathrm{O}_{3}$ contents are slightly higher (by $<2$ wt $\%)$ than the natural whole-rock contents, while the modeled $\mathrm{Na}_{2} \mathrm{O}$ contents are slightly lower (by $<0.5 \mathrm{wt} \%$ ) than the natural whole-rock contents (Fig. $6 \mathrm{a}, \mathrm{f})$. From the first solidification front to the residual magma chamber, the concentrations of $\mathrm{H}_{2} \mathrm{O}$ are predicted to have increased from $\sim 2.0$ to $3.5 \mathrm{wt} \%$ in the evolving liquids and from $\sim 0.8$ to $3.0 \mathrm{wt} \%$ in the bulk cumulates, respectively (Fig. 6g). 

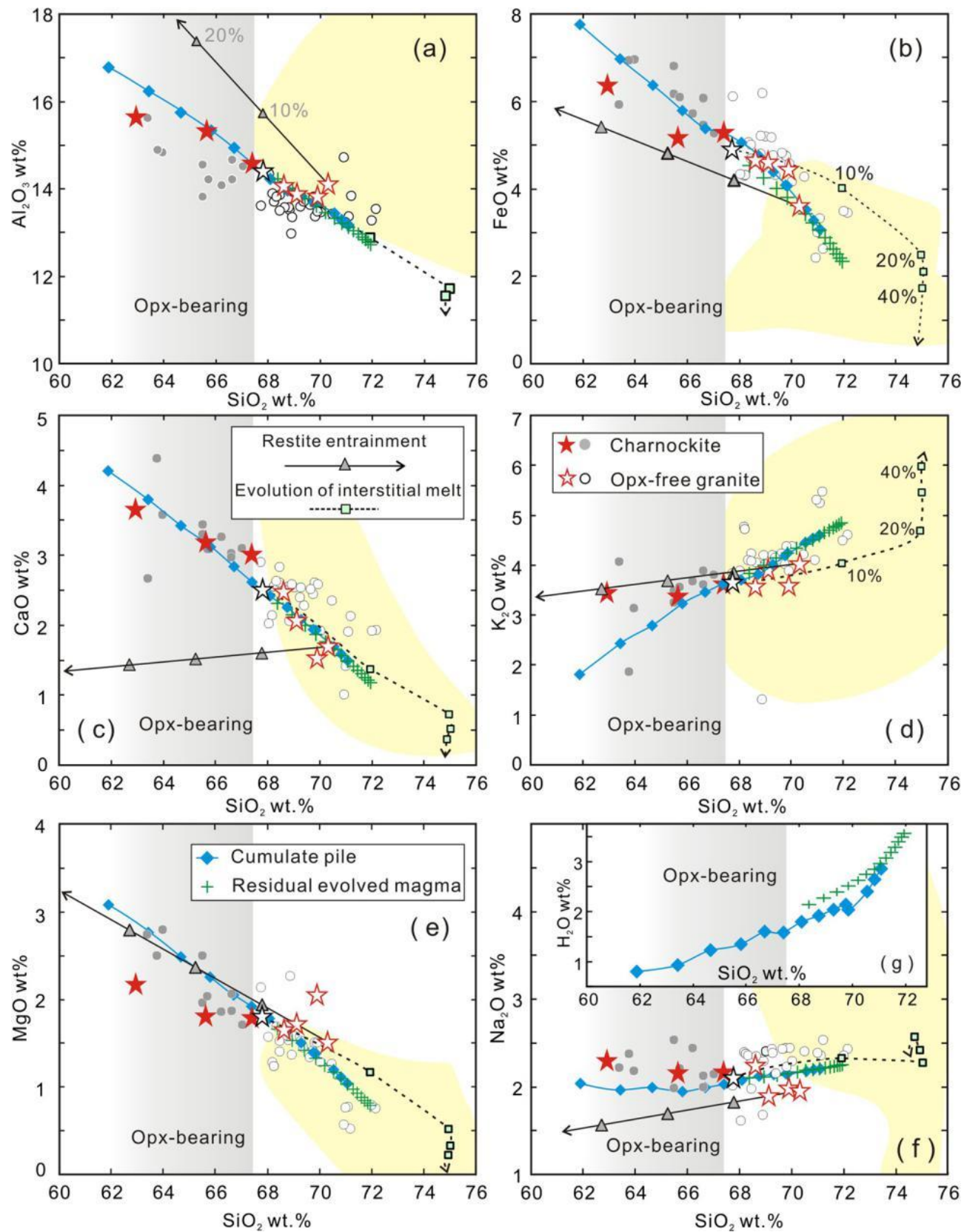

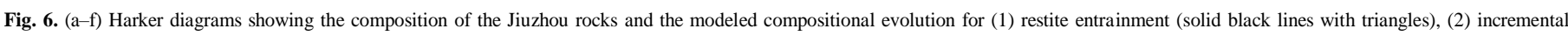

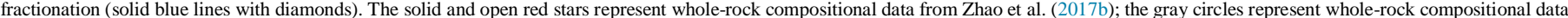

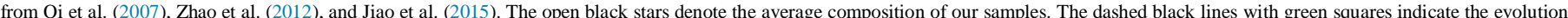

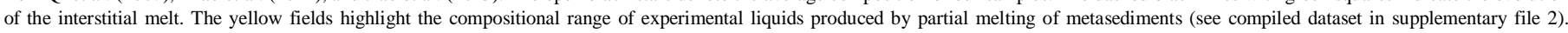

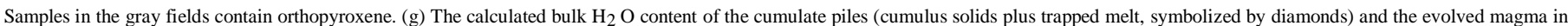
the residual magma chamber (symbolized by crosses) for each modeled increment/solidification front.

\section{Discussion}

\subsection{Magma processes recorded in silicic magma systems: examples from the Jiuzhou pluton}

Many granitic intrusions worldwide have bulk compositions that deviate from pure liquid compositions (e.g. Montel and Vielzeuf, 1997). The Jiuzhou pluton is a case example, exposing granitic rocks with $\sim 63-72 \mathrm{wt} \% \mathrm{SiO}_{2}$ that partly differ from the compositions of experimentally produced melts (Fig. 6a-f). Pro-cesses that may have modified the composition of granitic magmas in general include i) magma mixing with mantle-derived melts; ii) entrainment of restitic material; and/or iii) fractional crystal- lization and cumulate formation. We show that these processes can be quantified by combining established geochemical and pet-rographic analysis with thermodynamic modeling.

\subsubsection{The role of mantle-derived melt input in the Jiuzhou magma system}

Peraluminous granites have mostly sedimentary sources, but many are now known to have experienced mixing with mantle-derived melt (e.g. Stevens et al., 2007). Previous work has shown that mantle-derived melts have made no significant contribution to the strongly peraluminous Jiuzhou pluton with its enriched $\mathrm{Sr}-\mathrm{Nd}-\mathrm{Hf}$ isotopic composition (Qi et al., 2007; Zhao et al., 2017b). The absence of microgranitoid enclaves, the normal zoning of pla- 
Table 1

Whole-rock compositions and calculated model compositions used in our numerical modeling.

\begin{tabular}{|c|c|c|c|c|c|c|c|}
\hline & $\mathrm{JZ} 01-1^{\mathrm{a}}$ & $\mathrm{JZ} 10^{\mathrm{b}}$ & Average $^{c}$ & Minimum melt $^{\mathrm{d}}$ & Minimum melt ${ }^{\mathrm{e}}$ & Parental magma ${ }^{\mathrm{f}}$ for JZ01-1 & Parental magma ${ }^{\mathrm{g}}$ for JZ10 \\
\hline $\mathrm{SiO}_{2}$ & 62.95 & 68.63 & 67.72 & 74.74 & 75.73 & 68.25 & 70.48 \\
\hline $\mathrm{TiO}_{2}$ & 1.11 & 0.74 & 0.80 & - & 0.28 & 0.63 & 0.54 \\
\hline $\mathrm{Al}_{2} \mathrm{O}_{3}$ & 15.63 & 14.05 & 14.48 & 14.70 & 12.96 & 13.86 & 13.34 \\
\hline $\mathrm{Fe}_{2} \mathrm{O}_{3} *$ & 7.06 & 5.15 & 5.40 & 1.91 & 1.71 & 4.56 & 4.04 \\
\hline $\mathrm{MnO}$ & 0.09 & 0.07 & 0.07 & - & 0.03 & 0.07 & 0.06 \\
\hline $\mathrm{MgO}$ & 2.16 & 1.64 & 1.80 & 0.31 & 0.31 & 1.30 & 1.23 \\
\hline $\mathrm{CaO}$ & 3.64 & 2.46 & 2.51 & 0.49 & 1.12 & 2.21 & 1.86 \\
\hline $\mathrm{Na}_{2} \mathrm{O}$ & 2.29 & 2.23 & 2.09 & 1.93 & 3.11 & 2.23 & 2.21 \\
\hline $\mathrm{K}_{2} \mathrm{O}$ & 3.43 & 3.56 & 3.63 & 6.52 & 4.85 & 4.52 & 4.24 \\
\hline $\mathrm{H}_{2} \mathrm{O}$ & - & - & - & 3.5 & - & 2.0 & 2.7 \\
\hline
\end{tabular}

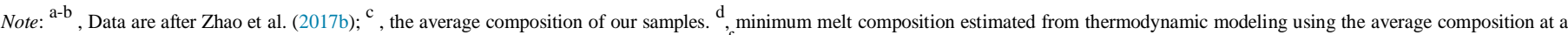

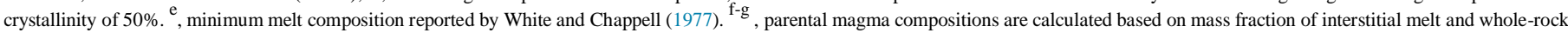

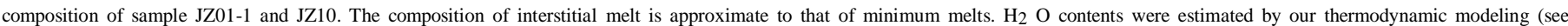
supplementary file 3). $\mathrm{Fe}_{2} \mathrm{O}_{3} *$ : all Fe reported as $\mathrm{Fe}_{2} \mathrm{O}_{3}$.

gioclase, and the lack of patchy zoning in plagioclase (Fig. 5a, d) or any of the other minerals, also preclude significant recharge by mantle-derived melts. The small-amplitude anorthite oscillations in plagioclase cores are likely a record of crystallization during early-stage convective stirring of the magma chamber and/or a reflection of melt boundary layer crystallization (e.g. Humphreys, 2009). The absence of mantle-derived melt input makes the Ji-uzhou pluton an ideal end-member for quantification with no complication of intermittent variation in composition or other in-tensive parameters.

5.1.2. The role of restite entrainment in the Jiuzhou magma system Peraluminous granites may contain variable amounts of restite (from a few inherited zircon cores to possibly several wt\%; e.g. Stevens et al., 2007). Restitic material is present and locally abun-dant in the Jiuzhou pluton, forming centimeter-size enclaves and micro-restite (Zhao et al., 2017b). The whole-rock geochemical trends, however, cannot be explained by restite entrainment as the restite is too plagioclase-depleted to reproduce the composi-tional variation (Fig. 6c). The volume of the observed micro-restite is moreover small $(<3 \mathrm{vol} \%)$, while restite entrainment would have had to be on the order of $20-30 \mathrm{wt} \%$ to account for the variations in all oxide components (Fig. 6a-f). Samples that do not contain visible restite may comprise largely assimilated restite components (e.g. that were assimilated as a result of decompression), but apart from minor amounts of xenocrysts (e.g. garnet) no evidence for such restite components exists even on the microscale. Orthopy-roxene crystals, including the biotite-rimmed crystals, represent primary magmatic crystals which were partially resorbed by their evolving host melt (Zhao et al., 2017a). We further note that our restite-

bearing samples (JZ04, JZ03-4) do not have the lowest $\mathrm{SiO}_{2}$ content, while

our sample with the lowest $\mathrm{SiO}_{2}$ content (JZ01-1) does not contain obvious micro-restite. We thus posit that restite entrainment has not exerted a major control on the compositional variation of the Jiuzhou pluton. For other granitic systems, it is im-perative to assess the amount and the type of restite present: If restite occurs in the form of xenoliths or xenocrysts, then all work has to focus on samples or sample fractions that are free of these components. If restite was assimilated, then it is crucial when and how much assimilation took place.

\subsubsection{The role of fractionation and cumulate formation in the Jiuzhou magma system}

Incremental fractionation with cumulate formation and melt extraction can explain the whole-rock compositional variation of the Jiuzhou pluton (as modeled in section 4.2 and shown in Fig. 6) and potentially that of other granitic plutons globally. In the fol-lowing, we discuss the record of mineralscale features. Part of the plagioclase crystals, i.e. $\sim 30 \%$ of the crystals in the charnockites and $\sim 50-90 \%$ of the crystals in the orthopyroxene-free granites, show characteristic step-zoning with subhedral to subround cores and partial to complete, low-anorthite overgrowths. Low-anorthite overgrowths may form by late- or post-magmatic fluid alteration, but this can be ruled out for the Jiuzhou system, as such alter-ation should have produced albite-rich compositions and zones rich in micro pores (e.g. Larsson et al., 2002), which are not ob-served.

Plagioclase with magmatic step-zoning is, however, also rel-atively common in some mafic igneous cumulates (Humphreys, 2009; Namur and Charlier, 2012; Namur et al., 2014). In these cumulates, part of the plagioclase crystals have largely unzoned cores, which are surrounded by a mantle with decreasing anor-thite content, followed by an overgrowth of constant low-anorthite composition with widths of up to several hundred micrometers. The plagioclase cores are mostly invoked to have formed at the top of a crystal mush and their mantles during burial in this mush (e.g. Namur et al., 2014). The unzoned overgrowths may reflect postcumulus growth of interstitial melt during continuous convec-tive melt exchange with a large, evolved melt reservoir (Namur and Charlier, 2012) or crystallization at decreasing undercooling buffered by latent heat release (Namur et al., 2014).

Convective melt exchange with a large melt reservoir may be possible in the case of mafic system, but not in the case of highly viscous silicic system at high crystal fraction (Huber et al., 2009; Glazner, 2014). Significant latent heat release at near-solidus conditions may have decreased undercooling in the solidi-fication fronts of the Jiuzhou system and buffered the composition of plagioclase and alkali feldspar overgrowths in the Jiuzhou sys-tem (cf. Namur et al., 2014). The largest amount of latent heat in granitic system is released by near-solidus crystallization (Huber et al., 2009). The calculated composition of the interstitial melt in the Jiuzhou system is close to a minimum composition (Table 1; Fig. 6), and we therefore posit that thermally and compositionally buffered crystallization of this melt at a ternary minimum pro-duced the compositionally unzoned overgrowths. The plagioclase and alkali feldspar overgrowths are partially developed on crystals in the charnockites (on $\sim 2 \%$ ) and orthopyroxene-free granites (on $\sim 4-6 \%$ ), which suggests partial (or significant) melt expulsion. The expulsion of this minimum melt upward in the crystal mush is in-ferred to have partially resorbed cumulus crystals (which typically have subhedral to subround cores) and then resumed crystalliza-tion at the ternary minimum. To our knowledge, quantitative stud-ies of mineral core-rim zoning from stratigraphically controlled granite samples that may record melt extraction are not available for comparison, but will be essential for further assessing the im-portance and for quantifying melt extraction processes in granitic magma system. 


\subsubsection{The driving forces of fractionation}

Mafic igneous cumulates, such as those of the Skaergaard intru-sion, are generally layered on the hand specimen- to outcrop-scale, characterized by contrasting mineral assemblages, modes, compo-sitions and/or textures (Holness et al., 2017). In the Jiuzhou plu-ton and in many granite intrusions worldwide, layering on the outcrop-scale is not developed, but a weak fabric may be evi-dent in hand specimen and thin section. For the Jiuzhou rocks, this fabric is defined by the preferred orientation of non-equant crystals and subparallel chains of plagioclase and other minerals (Fig. 2a and Fig. 3). It may have formed by magma flow (Holness et al., 2017), crystal settling (Jerram et al., 2003), and/or crystal-mush compaction (Philpotts et al., 1996). Viscous deformation by dislocation creep is locally recorded by (1) undulose extinction, subgrains, and deformation twins in plagioclase and rare bending of crystals (Fig. 2c-e); (2) rare undulose extinction and subgrains in alkali feldspar; (3) undulose extinction and chessboard subgrain patterns in quartz (Fig. 2d); and (4) bending and kinking of bi-otite (Fig. 2f). The deformation features observed in plagioclase, alkali feldspar, quartz, and biotite of the charnockites record lim-ited deformation by dislocation creep at super-solidus and/or at sub-solidus conditions, where the quartz chessboard subgrain patterns indicate viscous deformation at $>600{ }^{\circ} \mathrm{C}$ (Law, 2014). The relative scarcity of deformation features in weak phases such as biotite, their absence in the low-anorthite plagioclase overgrowths (Fig. 2e) and in the alkali feldspar rims and tendrils, are consis-tent with super-solidus deformation that ceased prior to interstitial melt crystallization, although minor subsolidus deformation may have affected biotite and quartz.

The contact boundaries of plagioclase crystals in crystal clus-ters and chains of the charnockites, which are characterized by long, mostly straight and at times slightly curved or serrated 2D outlines (Fig. 2a), may record heterogeneous nucleation, syn-neusis, or deformation-driven dissolutionreprecipitation/diffusion creep (e.g. Holness and Vernon, 2015). Heterogeneous nucleation should produce a random texture and not the observed preferred orientation of the rock-forming crystals. Synneusis would prefer-entially arrange crystals in a subparallel orientation along the lowenergy crystal faces (e.g. (010) interfaces of plagioclase, Vernon, 2004), which is not the case. Long contact lengths of crystals may also form by "welding", i.e. by dissolution-reprecipitation/diffu-sion creep under gravitational compaction (Schmidt et al., 2012). Deformation-driven dissolution-reprecipitation initially produces serrated contacts, but they rapidly anneal at high temperature (e.g. Mukai et al., 2014). The plagioclase and alkali-feldspar overgrowths are, moreover, asymmetrical on crystals in the charnockites, and the largest volumes of these overgrowths occur in apparent pres-sure shadow zones of the phenocrysts, which supports the interpretation that deformation-driven dissolution-reprecipitation was important (cf. Holness et al., 2017).

Viscous deformation should have been negligible in the case of fabric formation by magma flow and crystal settling, but im-portant in the case of viscous compaction (Holness et al., 2017; Fiedrich et al., 2017). We therefore suggest that the fabrics and the deformation of plagioclase, alkali feldspar, biotite and quartz in the charnockite are developed by crystal mush compaction with evi-dence for significant diffusion and limited dislocation creep, while a contribution of magmatic flow to the rock fabric cannot be ruled out. Below, we evaluate (1) if the magma mush in the Jiuzhou plu-ton was thick enough to self-compact; (2) if its compaction may have exerted enough strength to induce diffusion and/or disloca-tion creep.

\subsubsection{Compaction-driven fractionation}

In the absence of regional deformation, gravity-driven com-paction is commonly invoked to drive melt segregation in granitic magma system (e.g. Fiedrich et al., 2017). Gravity-driven com-paction, however, requires that the overlying crystal mush is thick and dense enough to provide sufficient strength, which can be as-sessed by the critical/characteristic compaction length (McKenzie, 1984). This length scale depends on the rheological properties of the crystal framework and the interstitial melt. The bulk and shear viscosities of the crystal framework have not been experimentally constrained, but can be conservatively estimated using the rhe-ological model of Caricchi et al. (2007) and Costa et al. (2009) (details are provided in supplementary file 1). For strain rates of $\sim 10^{-12}-10$ $-9 \mathrm{~s}^{-1}$ (cf. Nicolas and Ildefonse, 1996) and using the equations of McKenzie (1984), we further calculate effective

shear viscosities of $\sim 2 \times 10^{14}-10^{15} \mathrm{~Pa}$ s and bulk viscosities of $\sim 3 \times 10^{13}-2$ $\times 10^{14} \mathrm{~Pa}$ s at a porosity of $\sim 0.1$. At higher porosi-ties, the shear and the bulk viscosities of the crystal framework decrease. The shear viscosity of the interstitial melt with $\sim 75 \mathrm{wt} \% \mathrm{SiO}_{2}$ and $\sim 3.0 \mathrm{wt} \% \mathrm{H}_{2} \mathrm{O}_{5}$ at $\sim 800{ }^{\circ} \mathrm{C}$ and with $\sim 5.6 \mathrm{wt} \% \mathrm{H}_{2} \mathrm{O}$ at $\sim 750^{\circ} \mathrm{C}$ can be estimated to be $\sim 10^{5.4}-10{ }^{6.2} \mathrm{~Pa}$ s using the model of Giordano et al. (2008) (see details in supplementary file 1). Using these values, we then calculate a characteristic compaction length of $0.2-10 \mathrm{~m}$ for crystal mush at porosities of $\leq 0.1-0.5$ (as detailed in section 5 of supplementary file 1), which is close to the compaction length of $<1 \mathrm{~m}$ that has been estimated by Lee et al. (2015) for an evolved granite intrusion. Individual outcrops in the Jiuzhou pluton expose thicknesses of up to $\geq 100 \mathrm{~m}$ without significant layering or obvious internal contacts, which could represent individual sill or crystal mush layer (see details in section 5 in supplementary file 1). On the basis of our calculations, field ob-servations, and the systematic, vertical compositional pluton-scale zoning (Fig. 6 and Table S1), we thus conclude that compaction of the Jiuzhou crystal mush was physically feasible.

Evidence for viscous deformation (by diffusion and dislocation creep) increases from the stratigraphically lower, orthopyroxene-bearing units (charnockite sample JZ01, Fig. 2a and 3a), over the middle units (orthopyroxene-free granite sample JZ10, Fig. 3b), to the higher units (orthopyroxene-free granite sample JZ06, Fig. 2b and 3c). The CSD patterns determined for plagioclase are con-sistent with increasing crystal accumulation towards the lower stratigraphic levels of the pluton (Fig. 4). Two of our charnock-ite samples have concave CSD patterns, where curves are deflected upward for grain sizes of $>\sim 4 \mathrm{~mm}$ (Fig. 4). Such grain size distri-butions and CSD curves may reflect the modification of initially linear CSDs by crystal accumulation (Higgins, 1999). The small number of grains $<1 \mathrm{~mm}$ in size may reflect pressure dissolution by compaction (Schmidt et al., 2012), or limited nucleation of small crystals in the already crystal-rich cumulates (Holness and Ver-non, 2015). Our most evolved charnockite sample (JZ09) and the orthopyroxene-free granites, in contrast, have approximately linear CSDs (Fig. 4), which suggests that the accumulation of crystals was less significant (Higgins, 1999).

The strength required for deformation by diffusion and dis-location creep is estimated to have been $\sim 0.01-40 \mathrm{kPa}$ and $\sim 200-5000 \mathrm{kPa}$, respectively, for strain rates of $\sim 10^{-12}-10^{-9} \mathrm{~s}^{-1}$ (cf. Kirby and Kronenberg, 1987; Nicolas and Ildefonse, 1996; see calculations in supplementary file 1). For an estimated gravita-tional pressure gradient of $\sim 3 \mathrm{kPa} / \mathrm{m}$ (cf. Schmidt et al., 2012), a crystal mush layer $>0.01-10 \mathrm{~m}$ thick exerts then enough strength to induce diffusion creep, while a crystal mush layer $>70-1000 \mathrm{~m}$ thick is required to induce dislocation creep. Dislocation creep would thus have operated in a thicker mush layer and at a later stage of crystallization and compaction than diffusion creep, i.e. significant deformation by diffusion creep would have been fol-lowed by minor dislocation creep.

The undeformed, unzoned plagioclase and alkali feldspar over-growths are interpreted to have crystallized from trapped melt subsequent to mush compaction. In the charnockites and ortho- 
pyroxene-free granites, these overgrowths comprise $\sim 6$ vol\% and $\sim 18-22$ vol\%, respectively. A significant proportion of quartz (higher than that of plagioclase and alkali feldspar, cf. Wilke et al., 2015, 2017) must have also crystallized from the near-solidus interstitial melt, but the distribution of this late-stage quartz can-not be estimated on the basis of our petrographic observations and imaging. We can nevertheless roughly estimate the fraction of the quartz based on the modal proportion of low-anorthite and alkali feldspar overgrowths in the Qz-Ab-Or-An model system (Wilke et al., 2015), i.e. $\sim 4$ vol $\%$ for the charnockite and $\sim 11-13$ vol $\%$ for the orthopyroxene-free granite. We thus suggest that the proportion of trapped melt is significantly lower in the charnockites $(\sim 10$ vol\%) relative to the orthopyroxene-free granites ( 29-35 vol\%), which is consistent with their stratigraphically lower position and more primitive composition (Table S1 in supplementary file 1$)$.

The recorded amount of viscous deformation by dislocation creep in the Jiuzhou pluton - and in many other granite plu-tons worldwide - is significantly weaker than in many mafic layered series, e.g. in the Skaergaard intrusions (where disloca-tion creep may not have occurred at super-solidus conditions and for which viscous compaction remains controversial, Holness et al., 2017). However, as we have detailed above, deformation by diffusion creep (dissolution-reprecipitation) may be more impor-tant in silicic systems than deformation by dislocation creep. Ev-idence for diffusion creep may be elusive, as obvious markers for this process (e.g. truncated oscillatory zoning patterns indicat-ing partial dissolution) are rare. Further systematic and detailed microstructural studies for granite plutons are clearly needed to critically assess if (1) the recorded viscous deformation is caused by gravitationally-driven viscous compaction or other subsolidus processes; and (2) how important viscous compaction is as a fractionation driving force in general (e.g. Fiedrich et al., 2017; Holness, 2018).

\subsection{Thermodynamic modeling for cumulate systems}

Equilibrium thermodynamic modeling for partial disequilibrium cumulate systems is per se problematic and an oversimplifica-tion. For example, solidus plagioclase is predicted by thermody-namic modeling to crystallize with An48 composition from a magma with the composition of charnockite sample JZ01-1, and with An40 composition for a magma with the composition of the orthopyroxene-free granite sample JZ10 at system $\mathrm{H}_{2} \mathrm{O}$ con-tents of 1 and $2 \mathrm{wt} \%$ (see details of the modeling in supplemen-tary file 1). These modeled compositions of solidus plagioclase are lower than the average compositions of the analyzed plagio-clase crystals (excluding the mass and composition of the low-anorthite overgrowths), i.e. $\sim$ An50 and $\sim$ An47 in samples JZ01-1 and JZ10, respectively (Fig. 5c, f). If the cumulus phases of the magmas reached total equilibrium, then the thermodynamic mod-eling using sample JZ01-1 and JZ10 compositions should predict plagioclase compositions equivalent to those characteristic for the natural samples. If $\sim 10$ and $\sim 30 \mathrm{wt} \%$ of an evolved, interstitial melt with an invariant minimum composition (cf. Nishimura and Yanagi, 2000), i.e. with $\sim 75 \mathrm{wt} \%$ $\mathrm{SiO} 2$ (Table 1), is subtracted from the bulk composition of samples JZ01-1 and $\mathrm{JZ10}$, then plagioclase with $\sim \mathrm{An} 50$ and $\sim \mathrm{An} 47$ composition is predicted to crystallize at the solidus, matching the average composition of the natural crys-tals (Fig. $5 \mathrm{c}$ ). The fractions of trapped melt are thus inferred to have been $\sim 10 \pm 5 \mathrm{wt} \%(\sim 12 \pm 5 \%$ in volume $)$ and $\sim 30 \pm 5 \mathrm{wt} \%(\sim 33 \pm 5 \%$ in volume $)$ in the most mafic charnockite (JZ01-1) and in the most mafic orthopyroxenefree granite (JZ10) samples, re-spectively. These estimates are consistent with the estimated melt fractions based on our petrological observations (see section 5.1.4). They are lower than the porosities of loosely packed cumulates ( 50-60 vol\%, Schmidt et al., 2012), but are consistent with cu-
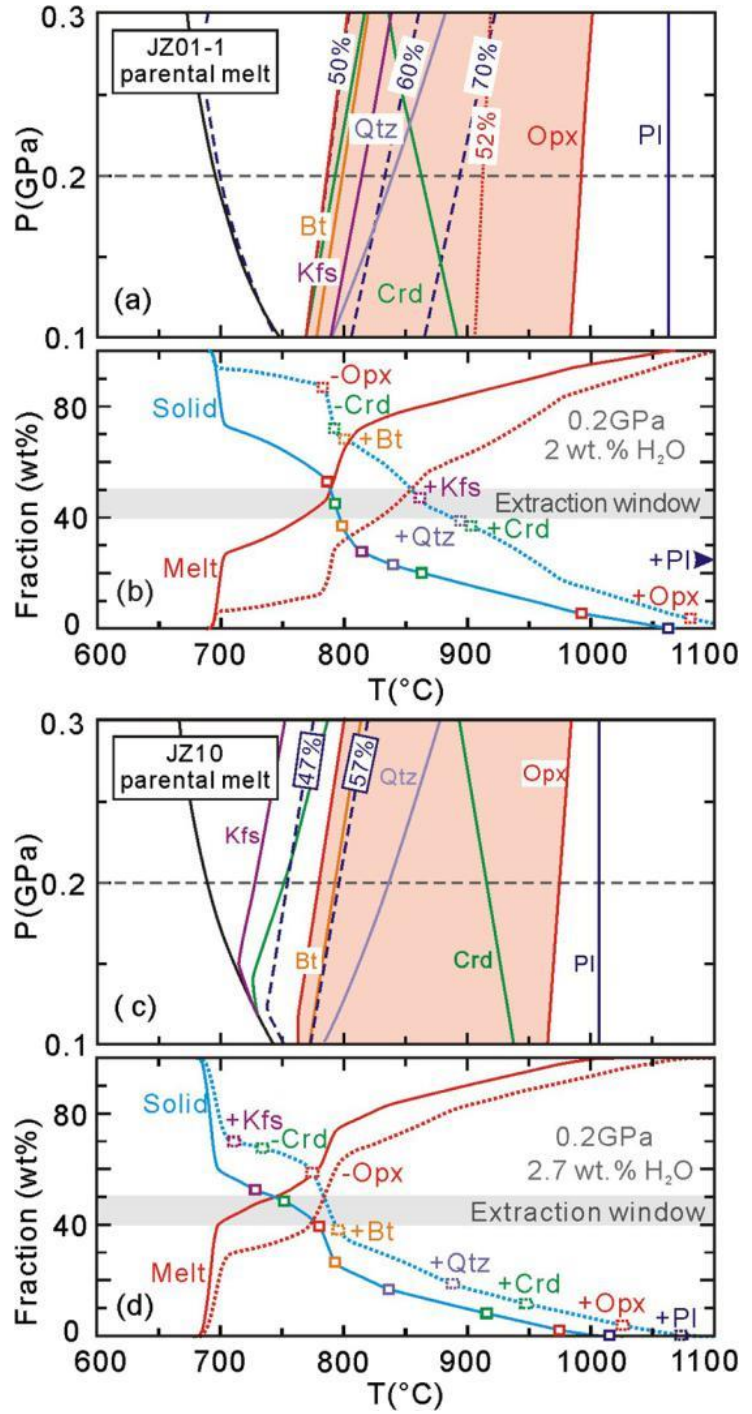

Fig. 7. Modeled P-T phase diagrams and modal abundance of crystals formed at $0.2 \mathrm{GPa}$ (fraction in wt \%) for the reconstructed parental magma compositions (Ta-ble 2) of sample JZ01-1 (a, b) and sample JZ10 (c, d). The dashed lines in (c) and (d) show the modeling results for sample JZ01-1 for an initial melt content of $2 \mathrm{wt} \%$ and for sample JZ10 for an initial 2.7 wt $\%$ melt $\mathrm{H}_{2} \mathrm{O}$ content (see detailed model-ing results in supplementary file 1). Solid lines (a, and b) mark the phase stability fields and dashed lines labeled with numbers denote the plagioclase anorthite iso-pleths (in mol\%). Phases are labeled inside their stability field. Solid and dotted blue lines with squares in $(b$, and $d$ ) denote the modeled crystallization sequence using the constructed parental magma compositions and bulk compositions of samples as a function of temperature and crystallinity. Note that the modeled alkali feldspar-, quartz- and cordierite-in boundaries for both compositions are comparable within $30-50{ }^{\circ} \mathrm{C}$, while the temperatures of biotite-in, orthopyroxene-out and cordierite-out boundaries do not change. Solid and dotted red lines in (b, $\mathrm{d}, \mathrm{f}$ and $\mathrm{h}$ ) denote the melt fraction as a function of temperature.

mulate porosities that can be achieved by predominantly mechan-ical compaction in the case of the orthopyroxene-free granites (cf. Higgins, 1991). The inferred trapped melt fraction of $\sim 10 \pm 5 \mathrm{wt} \%$ in the charnockites is consistent with mechanical compaction fol-lowed by significant viscous compaction (cf. Schmidt et al., 2012).

The fraction of melt lost from the solidification fronts during compaction can be further estimated to have been $\sim 40 \mathrm{wt} \%$ and $\sim 20 \mathrm{wt} \%$ for the charnockite and the orthopyroxene-free magmas, respectively, if we assume that melt extraction took place at a crys-tallinity of $\sim 50 \mathrm{wt} \%$. The composition of the parental magma (i.e. the magma from which the cumulus minerals crystallized) of the most primitive solidification front represented by the most mafic charnockite sample (JZ01-1) can thus be reconstructed to have had 

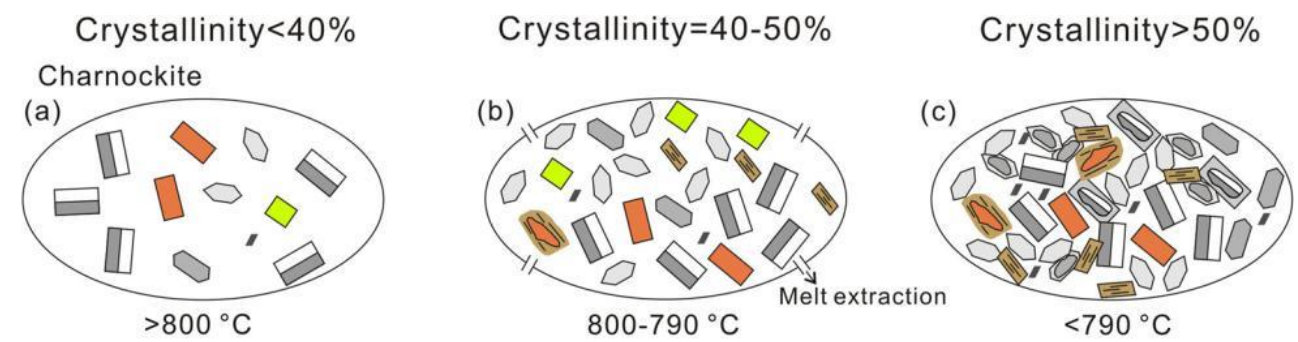

Orthopyroxene-free granite
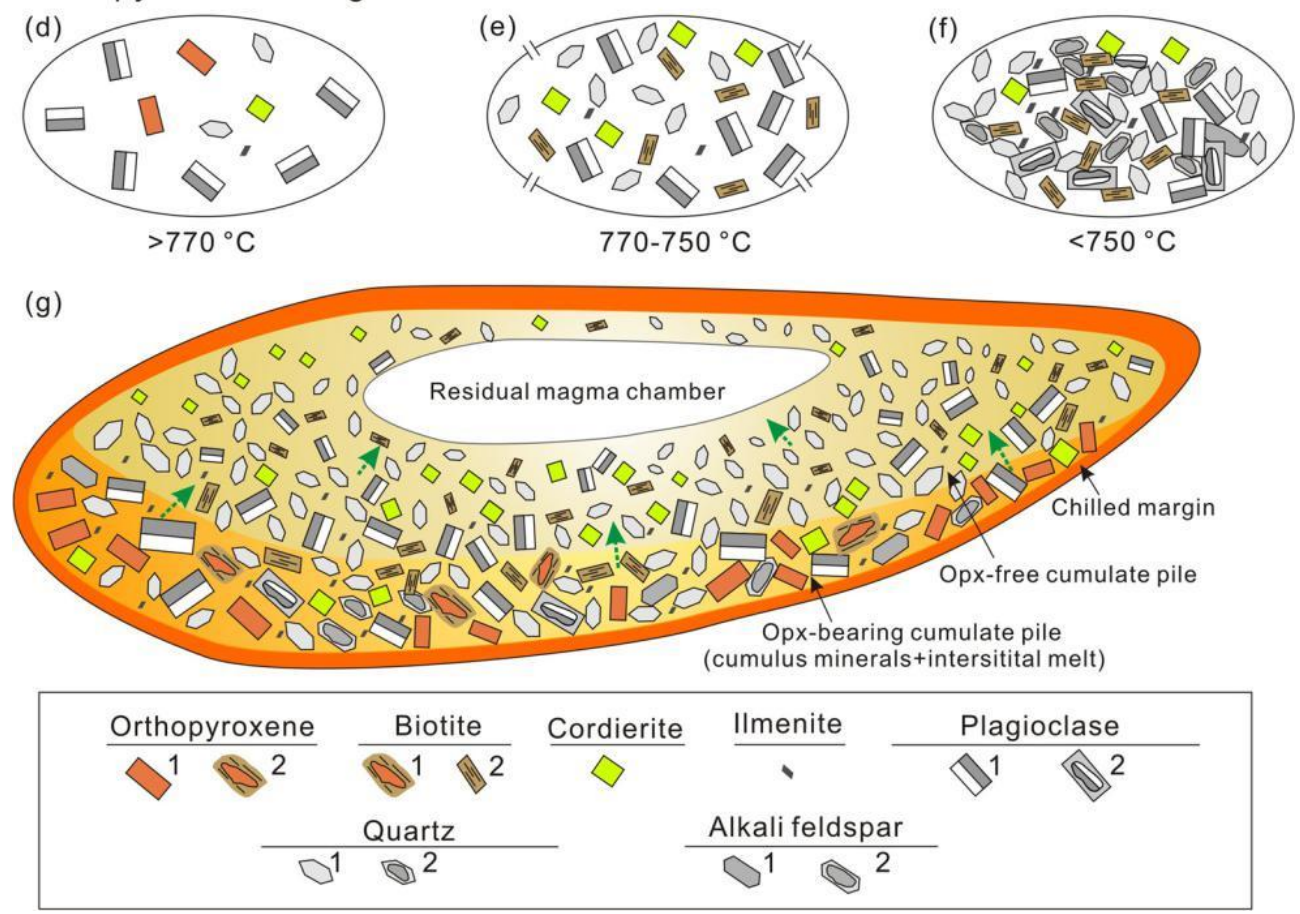

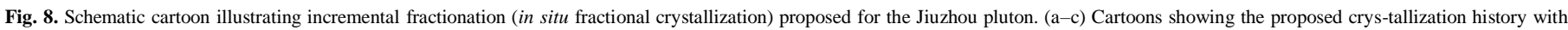

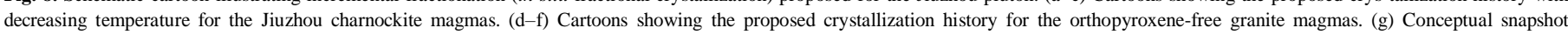

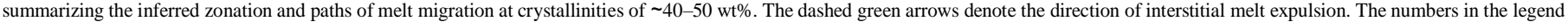

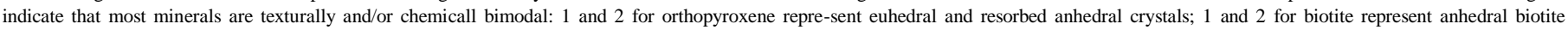

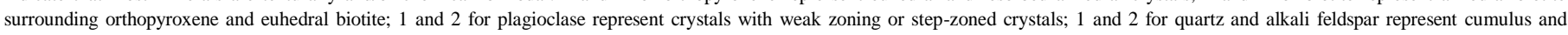
postcumulus crystals (see details in text).

$\sim 68 \mathrm{wt} \% \mathrm{SiO} 2$ (Table 1), which is close to the average compo-sition of all our samples, while the composition of the parental magma for the most mafic orthopyroxene-free sample (JZ10) is more evolved with $\sim 70 \mathrm{wt} \% \mathrm{SiO}_{2}$ (Table 1). Thermodynamic mod-eling using these reconstructed parental magma compositions will derive the most realistic constraints for opensystem fractiona-tion, while the uncertainties of thermodynamic modeling using cumulate compositions may be significant (Fig. 7; see details in section 5.3 in the supplementary file 1). We posit that thermody-namic modeling predicts comparable phase relations for relatively dry granitic system with moderately evolved composition at near solidus condition within $\leq 30-50{ }^{\circ} \mathrm{C}$ for fractionated systems with $\leq 30-45 \mathrm{wt} \%$ melt loss compared with the model results of the parental magma (with $68-70 \mathrm{wt} \% \mathrm{SiO}_{2}$ ). The modeling, however, overestimates the phase boundaries at near liquidus condition and thus the liquidus temperature by $50-80^{\circ} \mathrm{C}$. These uncertainties add to those inherent in the modeling approach $\left(\sim 20-60^{\circ} \mathrm{C}\right.$; Zhao et al., 2017a). The combined uncertainty may be small enough to be within the uncertainty of independent estimates (e.g. from con-ventional mineral thermometers) as in the case of the previously modeled phase relations for the Jiuzhou charnockite (Zhao et al., 2017a). The combined uncertainties may, however, also become significant $\left(\geq 100{ }^{\circ} \mathrm{C}\right)$, limiting a meaningful interpretation. Dise-quilibrium features, such as the step-zoned plagioclase crystals are thus important to be considered, even if their proportion appears relatively minor (as in our charnockite sample JZ01-1), and a re-construction of the parental magma composition is required.

\subsection{A conceptual model for fractionation and cumulate formation in silicic magma systems}

Fractionation of silicic magma systems is commonly consid-ered to involve the segregation of interstitial melt from a ho-mogeneous crystal mush (e.g. Bachmann and Bergantz, 2004; Gelman et al., 2014). The solid-rich fractionates of the Jiuzhou pluton are, however, not homogeneous, ranging from charnockite to orthopyroxene-free granite, advocating incremental fractiona-tion (e.g. as in the concept of Langmuir, 1989). Below, we build a conceptual model (Fig. 8a-g) for the magmatic evolution of the Ji-uzhou pluton using the most mafic charnockite sample JZ01-1 and the orthopyroxene-free granite sample JZ10 as end-members.

Thermodynamic modeling using the reconstructed parental magma composition predicts that plagioclase, orthopyroxene, quartz, alkali feldspar and biotite saturate at $>800-790^{\circ} \mathrm{C}$ and at crystallinities of $>40-50 \mathrm{wt} \%$ before melt extraction (Fig. 7a). The orthopyroxene-out boundary is predicted at $\sim 780^{\circ} \mathrm{C}$ and at a crystallinity of $\sim 55 \mathrm{wt} \%$; orthopyroxene is thus predicted to have been stable prior and subsequent to melt extraction (Fig. 7a). Melt 


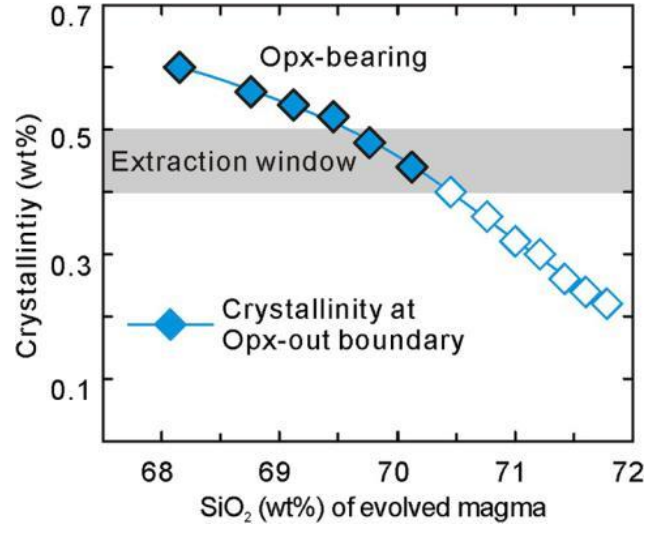

Fig. 9. The crystallinity at the orthopyroxene-out boundary as a function of evolving magma composition in the fractionating magma chamber in our model system (de-tails are reported in supplementary file 3). The gray area highlights the extraction window, i.e. the crystallinities for which melt extraction is inferred. Orthopyroxene was preserved only in solidification zones in which it formed early at crystallinities of $\geq 40 \%$.

extraction increases the survival chances of orthopyroxene, as this process leaves a relatively small proportion of melt for reaction with orthopyroxene. Many other granite plutons worldwide, specif-ically many garnet- and/or cordierite-bearing granites, may equally record such a fractionation process, as garnet and cordierite are commonly non-solidus phases similar with orthopyroxene in the Jiuzhou magmas.

In the more evolved orthopyroxene-free granites of the Ji-uzhou pluton, plagioclase, cordierite, quartz, and biotite saturate at $>770-750^{\circ} \mathrm{C}$ and $40-50$ wt $\%$ crystallinities, and thus before melt extraction (Fig. 7c). Orthopyroxene should have formed initially, but is totally resorbed at $\sim 780^{\circ} \mathrm{C}$ and at $\sim 40 \mathrm{wt} \%$ crystallinity (Fig. 7c). For magma more evolved than the orthopyroxene-free sample JZ10, the orthopyroxene stability field shrinks, i.e. the orthopyroxene-out boundary shifts from a crystallinity of $\sim 40 \mathrm{wt} \%$ for a magma with $\sim 70 \mathrm{wt} \% \mathrm{SiO}_{2}$ to a crystallinity of $\sim 20 \mathrm{wt} \%$ for a magma with $\sim 72 \mathrm{wt} \% \mathrm{SiO} 2$ (Fig. 9). The change of orthopy-roxene stability field with magma composition was, in addition to significant melt extraction, a key factor that permitted the local preservation of orthopyroxene in the marginal, relatively primitive solidification fronts of the Jiuzhou intrusion (Fig. 8g), yet not in the more evolved interior of the intrusion.

\section{Conclusions and implications}

Many volcanic and plutonic magma systems with intermediate to silicic compositions are invoked to have fractionated by crystal- liquid segregation, but microstructural evidence for this process is rarely reported. Our detailed microstructural observations re-vealed the crystal accumulation and melt extraction in the intru-sive magma body, and further combination of petrographic study with thermodynamic modeling quantitatively constrained the pro-portions of cumulate phases, trapped melt fractions and the composition of parental magma(s). For the studied Jiuzhou pluton, gravitational compaction has reduced the trapped melt fraction in crystal mush from $\sim 30$ $\mathrm{wt} \%$ at the upper level to $\sim 10 \mathrm{wt} \%$ at the lower level of the pluton, which results in the deviation of the whole-rock compositions from the metasediment-sourced experimental melt compositions. The studied rocks show continu-ous compositional zoning consistent with incremental fractionation from parental magmas with $\sim 68 \mathrm{wt} \% \mathrm{SiO} 2$ composition. Using the reconstructed parental magma as compared to whole-rock compo-sitions is crucial for thermodynamic modeling of phase relations and intensive parameters, which otherwise produce erroneous es-timates. Many granite plutons worldwide also have compositions deviating from those of primary melts, which may have experi-enced fractionation driven by gravitational compaction or by other processes such as hindered settling and gas-driven filter pressing. Detailed microstructural studies combining thermodynamic mod-eling for such systems will permit a critical appraisal of their frac-tionation processes with implications for understanding plutonic- volcanic connections, formation of mineral deposits and crustal differentiation.

\section{Acknowledgements}

We would like to sincerely thank Editor Tamsin Mather, re-viewer Chris Huber, and an anonymous reviewer for their many constructive comments and suggestions, especially those related to the role of deformation and compaction. We would also like to thank Guan C.G. and Zhou W.M. for access to their facility and support with the cathodoluminescence imaging. This work was fi-nancially supported by the Natural Science Foundation of China (41430208) and the program B for Outstanding $\mathrm{PhD}$ candidates at Nanjing University (201702B071).

\section{Appendix A. Supplementary material}

Supplementary material related to this article can be found on-line at https://doi.org/10.1016/j.eps1.2018.07.039.

\section{References}

Bachmann, O., Bergantz, G.W., 2004. On the origin of crystal-poor rhyolites: ex-tracted from batholithic crystal mushes. J. Petrol. 45, 1565-1582.

Caricchi, L., Burlini, L., Ulmer, P., Gerya, T., Vassalli, M., Papale, P., 2007. Non-Newtonian rheology of crystal-bearing magmas and implications for magma ascent dynamics. Earth Planet. Sci. Lett. 264, 402-419.

Connolly, J.A.D., 2005. Computation of phase equilibria by linear programming: a tool for geodynamic modeling and its application to subduction zone decarbon-ation. Earth Planet. Sci. Lett. 236, 524-541.

Costa, A., Caricchi, L., Bagdassarov, N., 2009. A model for the rheology of particle-bearing suspensions and partially molten rocks. Geochem. Geophys. Geosyst. 10, 1-13.

Fiedrich, A.M., Bachmann, O., Ulmer, P., Deering, C.D., Kunze, K., Leuthold, J., 2017. Mineralogical, geochemical, and textural indicators of crystal accumulation in the Adamello Batholith (northern Italy). Am. Mineral. 102, 2467-2483.

Gelman, S.E., Deering, C.D., Bachmann, O., Huber, C., Gutiérrez, F.J., 2014. Identifying the crystal graveyards remaining after large silicic eruptions. Earth Planet. Sci. Lett. 403, 299306.

Giordano, D., Russell, J.K., Dingwell, D.B., 2008. Viscosity of magmatic liquids: a model. Earth Planet. Sci. Lett. 271, 123-134.

Glazner, A.F., 2014. Magmatic life at low Reynolds number. Geology 42, 935-938. Gualda,

G.A.R., Ghiorso, M.S., Lemons, R.V., Carley, T.L., 2012. Rhyolite-MELTS: a modified calibration of MELTS optimized for silica-rich, fluid-bearing magmatic systems. J. Petrol. 53, 875-890.

Hertogen, J., Mareels, J., 2016. SilMush: a procedure for modeling of the geochemical evolution of silicic magmas and granitic rocks. Geochim. Cosmochim. Acta 185, 498-527.

Higgins, M.D., 1991. The origin of laminated and massive anorthosite, Sept Iles lay-ered intrusion, Québec, Canada. Contrib. Mineral. Petrol. 106, 340-354.

Higgins, M.D., 1999. Origin of megacrysts in granitoids by textural coarsening: a crystal size distribution (CSD) study of microcline in the Cathedral Peak Gran-odiorite, Sierra Nevada, California. Geol. Soc. (Lond.) Spec. Publ. 168, 207-219.

Holness, M.B., 2018. Melt segregation from silicic crystal mushes: a critical ap-praisal of possible mechanisms and their microstructural record. Contrib. Min-eral. Petrol. 173.

Holness, M.B., Vernon, R.H., 2015. The influence of interfacial energies on igneous microstructures. In: Charlier, B., Namur, O., Latypov, R., Tegner, C. (Eds.), Layered Intrusions. Springer Netherlands, Dordrecht, pp. 183-228.

Holness, M.B., Vukmanovic, Z., Mariani, E., 2017. Assessing the role of compaction in the formation of adcumulates: a microstructural perspective. J. Petrol. 58, 643-673.

Huber, C., Bachmann, O., Manga, M., 2009. Homogenization processes in silicic magma chambers by stirring and mushification (latent heat buffering). Earth Planet. Sci. Lett. 283, 38-47.

Humphreys, M.C.S., 2009. Chemical evolution of intercumulus liquid, as recorded in plagioclase overgrowth rims from the Skaergaard intrusion. J. Petrol. 50, 127-145. 
Jerram, D.A., Cheadle, M.J., Philpotts, A.R., 2003. Quantifying the building blocks of igneous rocks: are clustered crystal frameworks the foundation? J. Petrol. 44, 2033-2051.

Jiao, S.-J., Li, X.-H., Huang, H.-Q., Deng, X.-G., 2015. Metasedimentary melting in the formation of charnockite: Petrological and zircon $\mathrm{U}-\mathrm{Pb}-\mathrm{Hf}-\mathrm{O}$ isotope evidence from the Darongshan S-type granitic complex in southern China. Lithos 239, 217-233.

Keller, C.B., Schoene, B., Barboni, M., Samperton, K.M., Husson, J.M., 2015. Volcanicplutonic parity and the differentiation of the continental crust. Nature 523, 301-307.

Kirby, S.I., Kronenberg, A.K., 1987. Rheology of the lithosphere: selected topics. Rev. Geophys. 25, 1219-1244

Langmuir, C.H., 1989. Geochemical consequences of in situ crystallization. Na-ture 340, 199 205

Larsson, D., Gronvold, K., Oskarsson, N., Gunnlaugsson, E., 2002. Hydrothermal al-teration of plagioclase and growth of secondary feldspar in the Hengill Volcanic Centre, SW Iceland. J. Volcanol. Geotherm. Res. 114, 275-290.

Latypov, R., Egorova, V., 2012. Plagioclase compositions give evidence for in situ crystallization under horizontal flow conditions in mafic sills. Geology 40, 883-886.

Law, R.D., 2014. Deformation thermometry based on quartz c-axis fabrics and re-crystallization microstructures: a review. J. Struct. Geol. 66, 129-161.

Lee, C.-T.A., Morton, D.M., 2015. High silica granites: terminal porosity and crystal settling in shallow magma chambers. Earth Planet. Sci. Lett. 409, 23-31.

Lee, C.-T.A., Morton, D.M., Farner, M.J., Moitra, P., 2015. Field and model constraints on silicic melt segregation by compaction/hindered settling: the role of water and its effect on latent heat release. Am. Mineral. 100, 1762-1777.

McKenzie, D.P., 1984. The generation and compaction of partially molten rock. J. Petrol. 25, 713-765

Montel, J.M., Vielzeuf, D., 1997. Partial melting of metagreywackes, part II. Compo-sitions of minerals and melts. Contrib. Mineral. Petrol. 128, 176-196.

Mukai, H., Austrheim, H., Putnis, C.V., Putnis, A., 2014. Textural evolution of plagio-clase feldspar across a shear zone: implications for deformation mechanism and rock strength. J. Petrol. 55, 1457-1477.

Mustard, R., Ulrich, T., Kamenetsky, V.S., Mernagh, T., 2006. Gold and metal enrich-ment in natural granitic melts during fractional crystallization. Geology 34,85 .

Namur, O., Charlier, B., 2012. Efficiency of compaction and compositional convection during mafic crystal mush solidification: the Sept Iles layered intrusion, Canada. Contrib. Mineral. Petrol. 163, 1049-1068.

Namur, O., Humphreys, M.C.S., Holness, M.B., 2014. Crystallization of interstitial liquid and latent heat buffering in solidifying gabbros: Skaergaard intrusion, Greenland. J. Petrol. 55, $1389-1427$.

Nicolas, A., Ildefonse, B., 1996. Flow mechanism and viscosity in basaltic magma chambers. Geophys. Res. Lett. 23, 2013-2016.

Nishimura, K., Yanagi, T., 2000. In situ fractional crystallization observed in the Os-umi granodiorite batholith. Earth Planet. Sci. Lett. 180, 185-199.
Paterson, S.R., Fowler Jr., T.K., Schmidt, K.L., Yoshinobu, A.S., Yuan, E.S., Miller, R.B. 1998. Interpreting magmatic fabric patterns in plutons. Lithos 44, 53-82.

Philpotts, A.R., Carroll, M., Hill, J.M., 1996. Crystal-mush compaction and the origin of pegmatitic segregation sheets in a thick flood-basalt flow in the Mesozoic Hartford basin Connecticut. J. Petrol. 37, 811-836.

Qi, C.S., Deng, X.G., Li, W.X., Li, X.H., Yang, Y.H., Xie, L.W., 2007. Origin of the Darongshan-Shiwandashan S-type granitoid belt from southeastern Guangxi: geochemical and $\mathrm{Sr}-\mathrm{Nd}-\mathrm{Hf}$ isotopic constraints. Acta Petrol. Sin. 23, 403-412.

Schmidt, M.W., Forien, M., Solferino, G., Bagdassarov, N., 2012. Settling and com-paction of olivine in basaltic magmas: an experimental study on the time scales of cumulate formation. Contrib. Mineral. Petrol. 164, 959-976.

Spera, F.J., Bohrson, W.A., 2001. Energy-constrained open-system magmatic pro-cesses I general model and energy-constrained assimilation and fractional crys-tallization (ECAFC) formulation. J. Petrol. 42, 999-1018.

Stevens, G., Villaros, A., Moyen, J.-F., 2007. Selective peritectic garnet entrainment as the origin of geochemical diversity in S-type granites. Geology 35, 9 .

Vernon, R.H., 2004. A Practical Guide to Rock Microstructures. Cambridge University Press, Cambridge.

Wager, L.R., Brown, G.M., Wadsworth, W.J., 1960. Types of igneous cumulates. J. Petrol. 1, 73-85.

White, A.J.R., Chappell, B.W., 1977. Ultrametamorphism and granitoid genesis. Tectonophysics 43, 7-22.

Whitney, D.L., Evans, B.W., 2010. Abbreviations for names of rock-forming minerals. Am. Mineral. 95, 185-187.

Wilke, S., Holtz, F., Neave, D.A., Almeev, R., 2017. The effect of anorthite content and water on quartz-feldspar cotectic compositions in the rhyolitic system and implications for geobarometry. J. Petrol. 58, 789-818.

Wilke, S., Klahn, C., Bolte, T., Almeev, R., Holtz, F., 2015. Experimental investigation of the effect of $\mathrm{Ca}, \mathrm{Fe}$ and $\mathrm{Ti}$ on cotectic compositions of the rhyolitic system. Eur. J. Mineral. 27, 147-159.

Zak, J., Paterson, S.R., Memeti, V., 2007. Four magmatic fabrics in the Tuolumne batholith, central Sierra Nevada, California (USA): implications for interpreting fabric patterns in plutons and evolution of magma chambers in the upper crust. Geol. Soc. Am. Bull. 119, 184-201.

Zhao, K., Xu, X., Erdmann, S., 2017a. Crystallization conditions of peraluminous charnockites: constraints from mineral thermometry and thermodynamic mod-elling. Contrib. Mineral. Petrol. 172.

Zhao, K., Xu, X., Erdmann, S., Liu, L., Xia, Y., 2017b. Rapid migration of a magma source from mid- to deep-crustal levels: insights from restitic granulite enclaves and anatectic granite. Geol. Soc. Am. Bull. 129, 1708-1725.

Zhao, L., Guo, F., Fan, W., Li, C., Qin, X., Li, H., 2012. Origin of the granulite enclaves in Indo-Sinian peraluminous granites, South China and its implication for crustal anatexis. Lithos 150, 209-226. 